\title{
Ground Pressure Changes Caused by MHT 8002HV Crawler Harvester Chassis
}

\author{
Mariusz Kormanek, Jiř́ Dvořák
}

\begin{abstract}
Ground contact pressures exerted by elements of the machine chassis on the ground in the forest are associated with the machine impact on the soil during its operation. In the case of a crawler system, determining the ground contact pressure appears simple, which is not entirely true. The aim of the study was to analyze the loads on the ground (forest soil) exerted by the MHT 8002HV crawler harvester chassis. The measurements were made in Forest School Enterprise in Kostelec nad Černými Lesy, Central Bohemia Region in the Czech Republic, on brown soil made of clay on stony formations, fresh mixed mountain forest (FMMF), with the use of a hydraulic scale when extending the harvester crane forward along and perpendicular to the longitudinal axis of the machine. The calculations were carried out with a simulated load of the crane on the tree in question, assuming that the impact on the ground of the crawler system is heterogeneous and that the point impact comes from the crawler support wheels. As it was shown, the average ground contact pressures under the crawler track of the analyzed harvester generally do not exceed $70 \mathrm{kPa}$. The crane extension with a simulated load, which would have caused the crawler track to act on the ground with an average pressure exceeding $70 \mathrm{kPa}$, was limited by machine stability. On the other hand, high ground contact pressures may occur under a more loaded section of the crawler track if the active length of the crawler track is shortened. As it was shown in the case of a weak track tension, the course of ground contact pressures exerted on the soil deviates from the assumed usually homogeneous impact over the entire length of the crawler.
\end{abstract}

Keywords: crawler tractor, ground contact pressure, forest soil, track tension

\section{Introduction}

The basic factors associated with the machine, which determine the extent of its impact on the soil in the forest, are the ground contact pressure exerted by the elements of the chassis, shear stress caused by the chassis and vibrations transmitted to the ground (Ampoorter et al. 2007, 2010, Cambi et al. 2015, Solgi et al. 2019). It is suggested that ground contact pressure of machines that move in forests should be no more than $50 \mathrm{kPa}$ (Matthies et al. 1995, Więsik 1996); unfortunately, few machines meet this criterion. In practice, depending on the type of chassis, machines working in the forest exert an average ground contact pressure of 50 to 300 kPa (Malík and Dvořák 2007, Neruda 2008, Poršinsky et al. 2012). Due to the undesirable changes that could arise in the soil after the machines have passed, the threshold values above which the effects of the pressure may appear are assumed to be $70 \mathrm{kPa}$ for tracked systems and $150 \mathrm{kPa}$ for wheeled systems (Więsik 1996, Neruda 2008). The possibility of carrying out mechanized timber harvesting in demanding terrain conditions, i.e. in mountain areas, with machines is determined by a specific chassis design. Wheeled harvesters are suitable for slopes up to $35 \%$, while for slopes over $35 \%$ only tracked, tethered or walking harvesters can be used (Adams 1982, Braunack 1986, Kramer et al. 2007, Dvořák et al. 2011, Visser and Stampfer 2015, Ismoilow 2016). The advantage of tracked systems over wheeled ones is high stability and low ground contact pressure, resulting from the large contact area between the track and the ground. This allows the use of this type of vehicles not only in conditions of high slopes, but also in areas with low load capacity (Kramer et al. 2007, Poršinsky et al. 2012, Cambi et al. 2015). Low ground contact pressure is of particular importance in the context of ground damage that may occur after harvesting or extracting. An 
increase in soil compaction expressed by measuring soil bulk density or soil shear strength is considered to be the main negative effect of the chassis impact on the soil (Adams 1981, Akay et al. 2007, Sakai 2008, Allman et al. 2015, Kormanek et al. 2015ab). Finally, the most visible effect of soil compaction is the appearance of ruts caused by single or multiple passes of the machine (Naghdi and Solgi 2014, Haas et al. 2015). Mixing of the top soil layer, its compaction and displacement in combination with rut compaction can have a negative environmental impact (Haas 2015, Cambi et al. 2015, Solgi et al. 2019). Many authors indicate that changes that occur in the soil as a result of machine wood harvesting can significantly affect the quality of growing trees, cause the deterioration of forest health, and also slow early development of seedlings (Ulrich et al. 2003, Murphy 2004, Lukáč 2005, Ampoorter et al. 2007, Malík and Dvořák 2007, Naghdi at al. 2016, Solgi at al. 2019). According to Matthies et al. (1995), the resulting damage can affect the growth of trees up to $15 \mathrm{~m}$ on both sides of the skidding trail. As a rule, there is a reduction in the height and diameter of the trees, which affects the productivity of the stand (Williamson and Neilsen 2003, Murphy et al. 2004, Tan et al. 2006, Wijekoon et al. 2012). According to Becker, significant damage to the soil may cause a decrease in tree productivity usually by 10 to $15 \%$ or even up to $17 \%$ (Ulrich et al. 2003).

For wheeled chassis, it is problematic to determine the ground contact pressure that a pneumatic wheel exerts on the ground alone (Saarilahti 2002, Cambi et al. 2015, Marusiak and Neruda 2018). In the case of a crawler system, especially with all-steel crawler tracks, determining the ground contact pressure appears simple, as it is easy to determine the contact surface of the track with the ground. As a rule, the manufacturers' catalogues of crawler harvesters indicate the average static ground contact pressure that the elements of the unloaded machine track system exert on the soil (Inf. Mat. 2005). There is little information on the variation of the ground contact pressures exerted by this type of chassis depending on the working conditions of the machine (Cambi et al. 2015).

Taking into account the above mentioned findings, the aim of this study was to analyze the changes in ground contact pressure exerted on the forest soil by the MHT 8002HV crawler harvester chassis with variable direction and degree of extension of the machine crane, with or without load.

\section{Materials and Methods}

Measurements to determine pressure changes on the ground in the forest where made in Forest School
Enterprise in Kostelec nad Černými Lesy, Central Bohemia Region in the Czech Republic, on brown soil made of clay on stony formations, fresh mixed mountain forest (FMMF), for tracked harvester MHT8002HV equipped with LogMax 928 head (Fig. 1, Table 1). As provided by the manufacturer, due to its small size, the machine can perform work in high stand compactness, and thanks to its short and wide tracks, it has very good maneuverability and can work on a lowcapacity ground, as according to the manufacturer, the ground contact pressure under the track is $37.3 \mathrm{kPa}$. The low center of gravity enables work on steep slopes (MHT8002HV 2005).

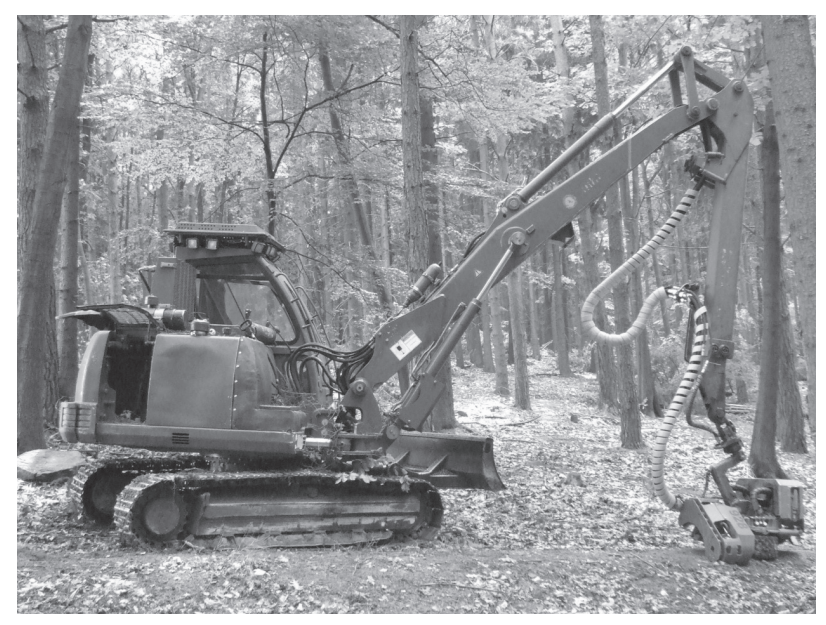

Fig. 1 MHT 8002 HV harvester with LOGMAX 928 harvester head

Table 1 Technical details of MHT 8002HV harvester and LOGMAX 928 head (MHT8002HV 2005)

\begin{tabular}{|c|c|c|c|}
\hline Specifications & Symbol & Unit & Value \\
\hline \multicolumn{4}{|c|}{ Harvester with crane MHT $8002 \mathrm{HV}$} \\
\hline Engine power & $M_{0}$ & kW & 43.8 \\
\hline Weight / mass with cabin & $G_{\mathrm{m}} / M_{\mathrm{m}}$ & $\mathrm{kN} / \mathrm{kg}$ & $81.4 / 8300$ \\
\hline Transport height / width / length & $H / L / G$ & $\mathrm{~m}$ & $2.85 / 2.15 / 7.4$ \\
\hline Speed & v & $\mathrm{km} \mathrm{h}^{-1}$ & $3.8-5.6$ \\
\hline Length / width of track / clearance & $d / a / p$ & m & $2.72 / 0.45 / 0.39$ \\
\hline Max. longitudinal / side inclination & $\alpha_{\max } / \beta_{\max }$ & $\circ$ & $21 / 14$ \\
\hline Ground contact pressure & $P_{\mathrm{i}}$ & $\mathrm{kPa}$ & 37.3 \\
\hline Maximum crane reach & $R$ & $\mathrm{~m}$ & 9.3 \\
\hline \multicolumn{4}{|c|}{ Harvester head LOGMAX 928} \\
\hline Weight with rotator & $G_{\mathrm{h}}$ & kN & 4.12 \\
\hline Cutting / trimming diameter & $D_{\mathrm{c}} / D_{0}$ & $\mathrm{~m}$ & $0.41 / 0.34$ \\
\hline
\end{tabular}




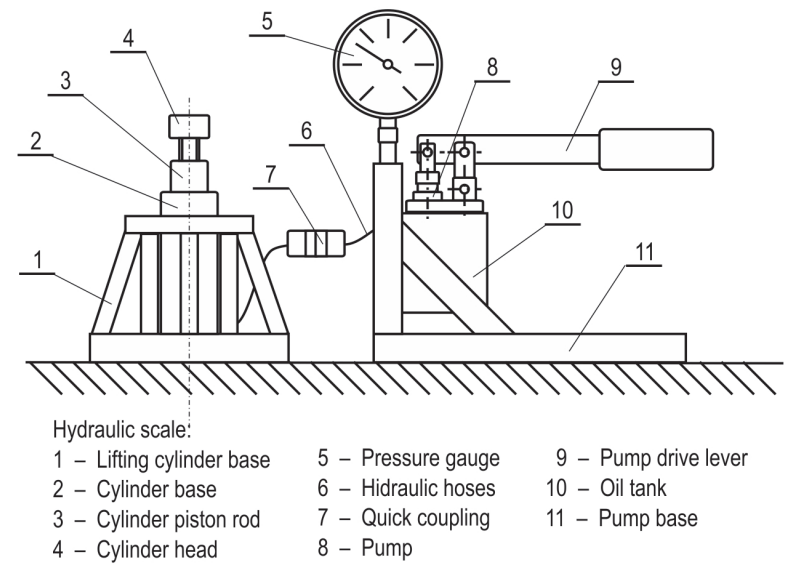

Fig. 2 Hydraulic scale

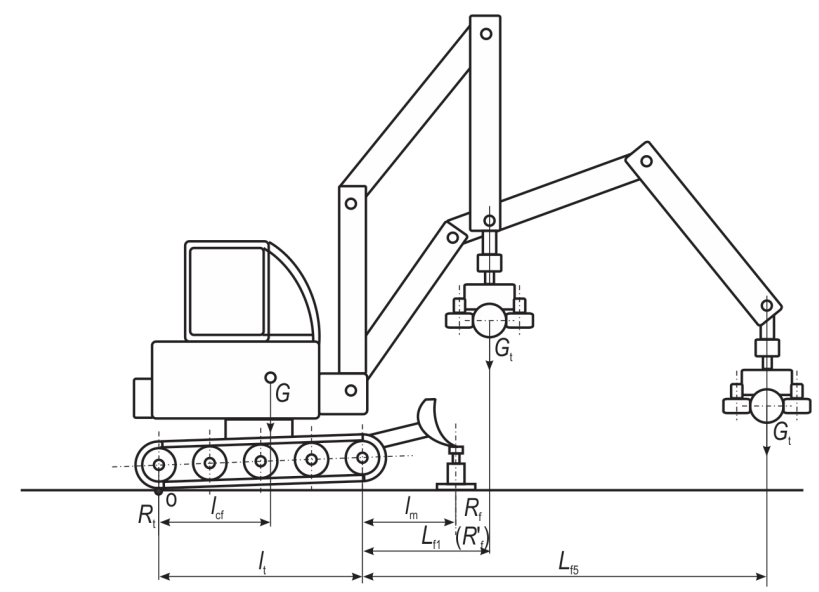

Fig. 3 Load measurement scheme for crawler harvester, extending the crane forward
In order to determine the ground contact pressure exerted by the tracks on the forest floor in flat terrain, the loads on the chassis were measured with a hydraulic scale (Fig. 2), with a measurement range up to 90 kN \pm 500 N (Kormanek 2016).

The measurements in the experiment were made in two variants. Variant 1 consisted in placing the lifting cylinder 2 of scale (Fig. 2) under a harvester mister, in the middle of its scraping edge $\left(l_{\mathrm{m}}\right)$ (Fig. 3 ) and lifting the harvester front to the position where the machine was supported on scale cylinder 2 at the front, and at the rear end wheels of the crawler. Then, the harvester crane was gradually moved forward along its longitudinal axis $\left(L_{\mathrm{f} 1} \div L_{\mathrm{f} 5}\right)$, and after stopping in each position, the value of load on the scale $\left(R_{\mathrm{f}}\right)$ was recorded (Fig. 3).

Variant 2 consisted in placing the lifting cylinder 2 of scale under the mister (Fig. 4), at the point of the scraper edge, whose distance across the machine corresponded to the distance from the outer edge of the right to the center of the left track.

After lifting the harvester front, the crane was gradually extended to the left side at an angle of $90^{\circ}$ to the machine longitudinal axis $\left(L_{\mathrm{s} 1} \div L_{\mathrm{s} 5}\right)$, and values from the scale $\left(R_{\mathrm{us}}\right)$ were recorded (Fig. 4 and Tab. 3). During the measurements, the height of the harvesting head above the ground was about $0.5 \mathrm{~m}$. Simulation calculations were also made on the assumption that the harvester carries a tree with a weight of $3 \mathrm{kN}$, which, after being felled, rests on the ground with the top part on the ground, while the tree trunk is grabbed by the head loading the crane with $G_{t}=2 \mathrm{kN}$.
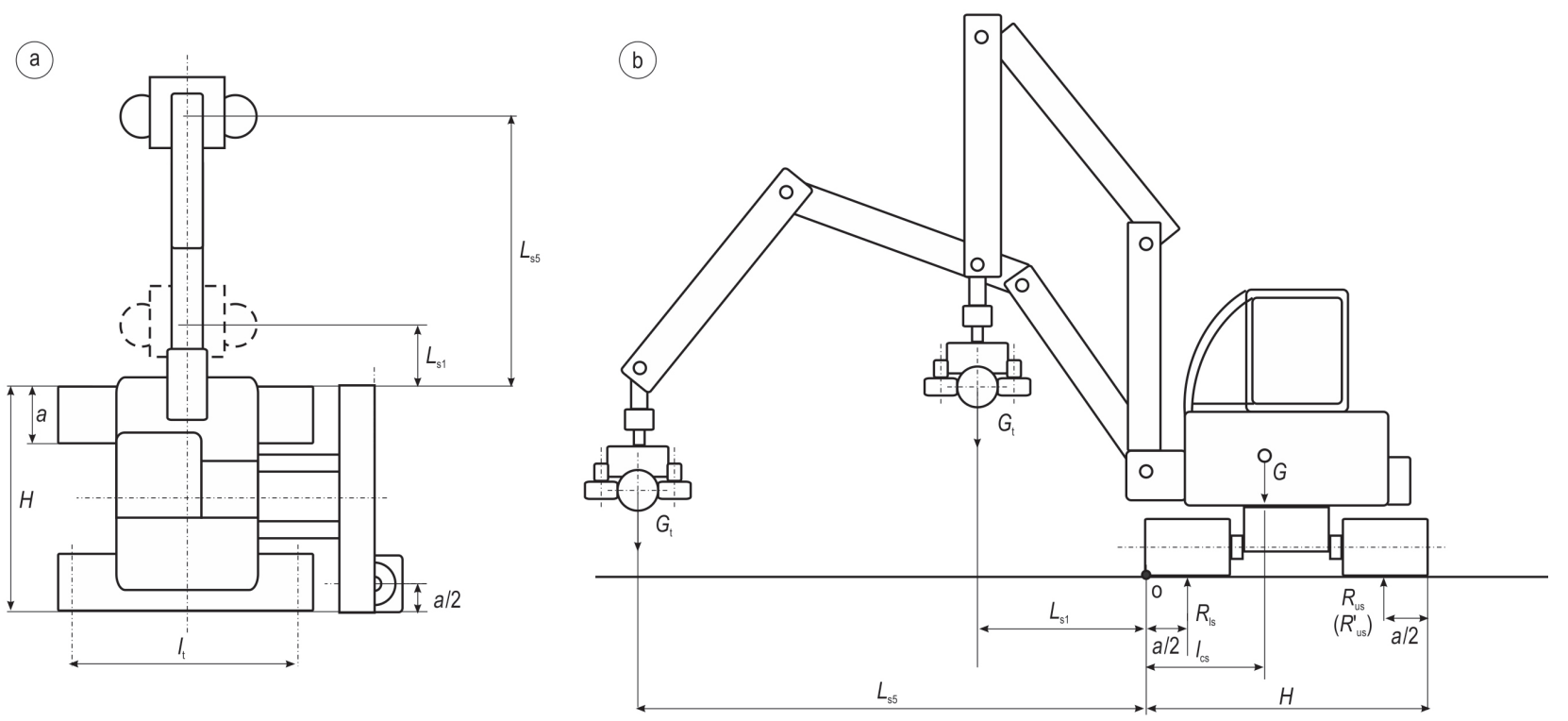

Fig. 4 Measurement scheme for harvester loads when extending the crane perpendicularly to machine longitudinal axis, view from above $-a$, view from a side $-b$ 


\section{Calculation method variant 1: crane along the machine}

For the calculation of the pressure exerted by the crawler tracks on the ground, first the position of the center of gravity along the machine $l_{\text {cf }}$ from the vertical axles of the rear end wheels of the crawler, with different positions of the crane and head, was determined according to Eq.1 (Dajniak 1974):

$$
G \cdot l_{\mathrm{cf}}=R_{\mathrm{f}} \cdot\left(l_{\mathrm{t}}+l_{\mathrm{m}}\right)
$$

Where:

G sum weight of harvester and harvester head, $\mathrm{kN}$

$l_{\mathrm{cf}}$ distance of center of gravity along the machine from rear wheel vertical axle, $\mathrm{m}$

$R_{\mathrm{f}} \quad$ vertical reaction on scale, $\mathrm{kN}$

$l_{\mathrm{t}} \quad$ length of track contact, $\mathrm{m}$

$l_{\mathrm{m}} \quad$ distance of weight scale location from the front wheel vertical axle, $\mathrm{m}$.

In equation (1), the weight per hydraulic scale is equal to the vertical reaction value $R_{\mathrm{f}}$, and the total machine weight $G$ is the sum of the weight of the harvester $G_{m}$ and the head $G_{h}$ (Table 1). The length of the track contact with the ground was assumed to be $l_{\mathrm{t}}=2.3 \mathrm{~m}$, while the distance of weight scale location from the front wheel axle $l_{\mathrm{m}}=0.95 \mathrm{~m}$, which was determined during field measurements. After determining the value of $l_{\mathrm{cf}}$, it was assumed that the resistance force of track $R_{\mathrm{y}}$ acts along the same vertical axis as the total weight of the machine $G$ and then $l_{R}=l_{\mathrm{c} f}$ and hence:

$$
l_{\mathrm{R}}=\frac{l_{\mathrm{t}}}{3} \cdot \frac{q_{2}+0.5 \cdot q_{1}}{q_{0}}
$$

Where:

$l_{\mathrm{R}} \quad$ distance of resistance force of track $R_{\mathrm{y}}$ along the machine, from rear wheel vertical axle, $\mathrm{m}$

$R_{\mathrm{y}} \quad$ resistance force of track, $\mathrm{N}$

$q_{1}, q_{2}$ highest and lowest contact pressures between track and ground per unit of track length, $\mathrm{N} \mathrm{m}^{-1}$ $q_{0} \quad$ average value of contact pressures between track and ground per unit of track length, $\mathrm{N} \mathrm{m}^{-1}$.

The mean value of the pressures $q_{0}$ between the track and the ground was determined from the relationship:

$$
q_{0}=0.5 \cdot\left(q_{1}+q_{2}\right)=\frac{R_{\mathrm{y}}}{l_{\mathrm{t}}}
$$

Using relationships (2) and (3), equations can be obtained to determine the highest and lowest unit pressures between the crawler track and the ground:

$$
q_{1}=2 \cdot q_{0} \cdot\left(2-3 \cdot \frac{l_{\mathrm{R}}}{l_{\mathrm{t}}}\right)
$$

$$
q_{2}=2 \cdot q_{0} \cdot\left(3-\frac{l_{\mathrm{R}}}{l_{\mathrm{t}}}-1\right)
$$

Equations (4) and (5) are valid when the minimum pressures $q_{2} \geq 0$ i.e., when:

$$
3 \cdot \frac{l_{\mathrm{R}}}{l_{\mathrm{t}}}-1 \geq 0 \rightarrow l_{\mathrm{R}} \geq \frac{l_{\mathrm{t}}}{3}
$$

when $l_{R}=l_{\mathrm{t}} / 3$ (minimum pressure $q_{2}=0$ ), the pressure distribution between the track and the ground is triangular. The case where (6) is not met indicates that the load on the ground from the track is triangular but is only carried by part of the surface of the track intended to be in contact with the ground. The active length of the contact surface of the track with the ground will then be equal to:

$$
l_{\mathrm{t}}^{\prime}=3 \cdot l_{\mathrm{R}}
$$

and the mean value of the pressure between the track and the ground:

$$
q_{0}^{\prime}=\frac{R_{\mathrm{y}}}{l_{\mathrm{t}^{\prime}}}
$$

Where:

$l_{t}^{\prime}$ active length of the contact surface of the track with the ground, $\mathrm{m}$

$q_{0}^{\prime}$ average value of contact pressures between track and ground per unit of active track length, $\mathrm{N} \mathrm{m}^{-1}$.

The highest pressure per unit length of crawler track under these conditions will be:

$$
q_{1}=2 \cdot q_{0}^{\prime}
$$

and the contact ground pressure at the front $P_{\mathrm{ff}}$ and at the rear $P_{\text {fr }}$ of the single track of width a (Table 1 ) is:

$$
P_{f f}=\frac{q_{1}}{2 \cdot a} ; P_{f r}=\frac{q_{1}}{2 \cdot a} ;
$$

Where:

$P_{\mathrm{ff}}$ contact ground pressure at the front of the single track, $\mathrm{Pa}$

$P_{\text {fr }}$ contact ground pressure at the rear of the single track, Pa.

For the calculation of the additional load from the tree $G_{t}$ the additional weight per scale was calculated $R_{\mathrm{f}}^{\prime}$ (11) and then, taking into account the increase in total machine weight to $G_{c}(12)$, the calculations were repeated as for the unladed variant:

$$
G_{\mathrm{t}} \cdot\left(l_{\mathrm{t}}+L_{\mathrm{f}}\right)=R_{\mathrm{f}}^{\prime} \cdot\left(l_{\mathrm{t}}+l_{\mathrm{m}}\right)
$$




$$
G_{\mathrm{c}}=G+G_{\mathrm{t}}
$$

Where:

$G_{t}$ additional load from the tree, $\mathrm{N}$

$R_{f}^{\prime}$ additional weight per scale, $\mathrm{N}$

$L_{\mathrm{f}}$ distance from vertical axles of the front end wheels of the truck to vertical axis of the weight of wood, $\mathrm{m}$

$G_{c}$ sum of harvester, harvester head and wood weight, $\mathrm{N}$.

\section{Calculation method variant 2: crane on the side of the machine}

In order to calculate the value of the pressure exerted by the track on the ground when the crane is extended perpendicularly to the longitudinal axis of the machine (Fig. 4), the positions of the center of gravity across the machine $l_{\text {cs }}$ from the extreme point of contact between the track and the ground and the weight scale were first determined (13):

$$
G \cdot l_{\mathrm{cs}}=\left(R_{\mathrm{us}} \cdot\left(H-\frac{a}{2}\right)\right) \cdot 2+\left(R_{\mathrm{ls}} \cdot \frac{a}{2}\right)
$$

Where:

$l_{\mathrm{cs}}$ distance of center of gravity across the machine from the external contact of the track, $m$

$R_{\text {us }}$ vertical reaction in the middle of unloaded truck, $\mathrm{kN}$

$R_{\mathrm{ls}}$ vertical reaction in the middle of loaded truck, $\mathrm{kN}$ $H$ width of the machine, $\mathrm{m}$.

It was assumed, for simplicity, that the value of the right (unloaded) track was equal to double weight indicated on the scale $R_{\mathrm{us}}$ and that their sum with reaction under the left loaded track $R_{\mathrm{ls}}$ was equal to the total weight of the machine with the harvester head $G$ (14):

$$
\left(R_{\mathrm{ls}}+2 \cdot R_{\mathrm{us}}\right)=G
$$

The ground contact pressure exerted by the left loaded $P_{1}$ and right unloaded track $P_{\mathrm{u}}$ was then calculated (15) as follows:

$$
P_{1}=\frac{R_{1 s}}{l_{\mathrm{t}} \cdot a} ; P_{\mathrm{u}}=\frac{2 \cdot R_{\mathrm{us}}}{l_{\mathrm{t}} \cdot a}
$$

Where:

$P_{1}$ ground contact pressure exerted by the left loaded truck, $\mathrm{Pa}$

$P_{\mathrm{u}}$ ground contact pressure exerted by the right unloaded truck, Pa.

For the calculation of the additional load from the tree $G_{t}$, first the reduction of weight on scale was calculated $R_{\mathrm{rs}}(16)$ and then, taking into account the in- crease in total machine weight to $G_{\mathrm{c}}(12)$ and changed weight on the scale $R_{\text {us }}^{\prime}(17)$, the calculations were repeated as for the unladed variant:

$$
\begin{gathered}
G_{\mathrm{t}} \cdot\left(L_{\mathrm{s}}\right)=2 \cdot\left(R_{\mathrm{rs}} \cdot\left(H-\frac{a}{2}\right)\right) \\
R_{\mathrm{us}}^{\prime}=R_{\mathrm{us}}-R_{\mathrm{rs}}
\end{gathered}
$$

Where:

$R_{\mathrm{rs}}$ reduction of weight on scale, due to the weight of the wood, $\mathrm{N}$

$R_{\mathrm{us}}$ change of weight on the scale, due to the weight of the wood, $\mathrm{N}$.

In addition to the usual contact ground pressure under the track, presented as homogeneous over the entire length of the crawler track, a model is used that takes into account the pointing effect of the individual wheels in the crawler track (Wang 2009) (18):

$$
P=\frac{G}{2 \cdot a \cdot l} \cdot\left(1+\cos \left(\frac{2 \cdot n \cdot \pi \cdot x}{l}\right)\right)
$$

Where:

$P$ ground contact pressure exerted along the track, Pa

$n$ number of cycles according to the number of maxima of impact on the ground equal to number of wheels (5 in harvester MHT 8002 HV),

$x$ distance from the extreme point of contact between the track and the ground, $\mathrm{m}$

$l$ length of the track equal to $l_{\mathrm{t}}$ or $l_{\mathrm{t}}{ }^{\prime}, \mathrm{m}$.

\section{Results}

As shown by the results of measurements and calculations (Table 2), when the crane was in transport position and the harvester head was close to the front of the machine, the center of mass of the machine was shifted back with respect to the center of the track. The rear extreme point of contact of the track was applied to the ground with a ground contact pressure of $52.4 \mathrm{kPa}$ and the front extreme point of contact with the ground with $30.2 \mathrm{kPa}$. The ground contact pressure under the track was trapezoidal, with a smaller base at the front of the track (Fig. 5A). When the crane was extended forward at a distance of $2.5 \mathrm{~m}, 3.5 \mathrm{~m}, 5.2 \mathrm{~m}$ and $8.2 \mathrm{~m}$, the center of gravity of the machine was gradually shifted forward causing the front of the track to be loaded (Table 3, Fig. 5A). For the crane extension of $2.5 \mathrm{~m}$, the ground contact pressure under the track was almost equal (the ground contact pressure under the track was close to rectangular). A situation, in which 
Table 2 Weight indications and results of calculation of active track length and track-ground contact pressures

\begin{tabular}{|c|c|c|c|c|c|c|c|c|}
\hline \multirow{2}{*}{\multicolumn{2}{|c|}{ Crane extension }} & \multirow{3}{*}{$\begin{array}{c}\text { Weight indications } \\
\text { on scale } R_{\mathrm{pf}}, \mathrm{KN}\end{array}$} & \multirow{3}{*}{$\begin{array}{c}\begin{array}{c}\text { Length of the } \\
\text { area of impact }\end{array} \\
I_{\mathrm{t}}\left(\mathrm{I}_{\mathrm{t}}^{\prime}\right), \mathrm{m}\end{array}$} & \multicolumn{5}{|c|}{ Ground contact pressure, $\mathrm{kPa}$} \\
\hline & & & & \multicolumn{3}{|c|}{ Homogeneous impact, track extremes } & \multicolumn{2}{|c|}{ Point impact, track extremes } \\
\hline Variant & Value, $\mathrm{m}$ & & & $P_{\text {avg }}$ & $P_{\mathrm{fr}}$ & $P_{\mathrm{ff}}$ & $P_{\mathrm{fr}}$ & $P_{\mathrm{ff}}$ \\
\hline$L_{f 1}$ & 1.8 & 27.6 & 2.3 & 41.3 & 52.4 & 30.2 & 104.8 & 60.1 \\
\hline$L_{\mathrm{f} 2}$ & 2.5 & 30.5 & 2.3 & 41.3 & 40.5 & 41.3 & 81.0 & 84.3 \\
\hline$L_{f 3}$ & 3.5 & 38.3 & 2.3 & 41.3 & 24.6 & 58.1 & 49.2 & 116.7 \\
\hline$L_{\mathrm{f} 4}$ & 5.2 & 48.5 & 2.3 & 41.3 & 0.0 & 82.6 & 0.0 & 170.3 \\
\hline$L_{f 5}$ & 8.2 & 48.5 & 1.37 & 69.2 & 0.0 & 138.4 & 0.0 & 276.8 \\
\hline
\end{tabular}

the extreme rear point of contact between the crawler track and the ground had a pressure of approximately $0 \mathrm{kPa}$, occurred when the crane was extended to $5.2 \mathrm{~m}$ and the ground contact pressure from the track was triangular, with the maximum value at the front of the track $(82.6 \mathrm{kPa})$. When the crane continued to extend forward, the length of active contact between the track and the ground was reduced from $l_{\mathrm{t}}$ to $l_{\mathrm{t}}$. With an extension distance of $8.2 \mathrm{~m}$, the active length of the track $l_{p}{ }^{\prime}$, which carried the load to the ground, was only $1.37 \mathrm{~m}\left(l_{\mathrm{t}}=2.3 \mathrm{~m}\right)$, while the ground contact pressure of the front end of the track reached $138.4 \mathrm{kPa}$. In the variant where it was assumed that the interaction of the chassis system only results from the interaction of the support wheels in the track, the course of changes

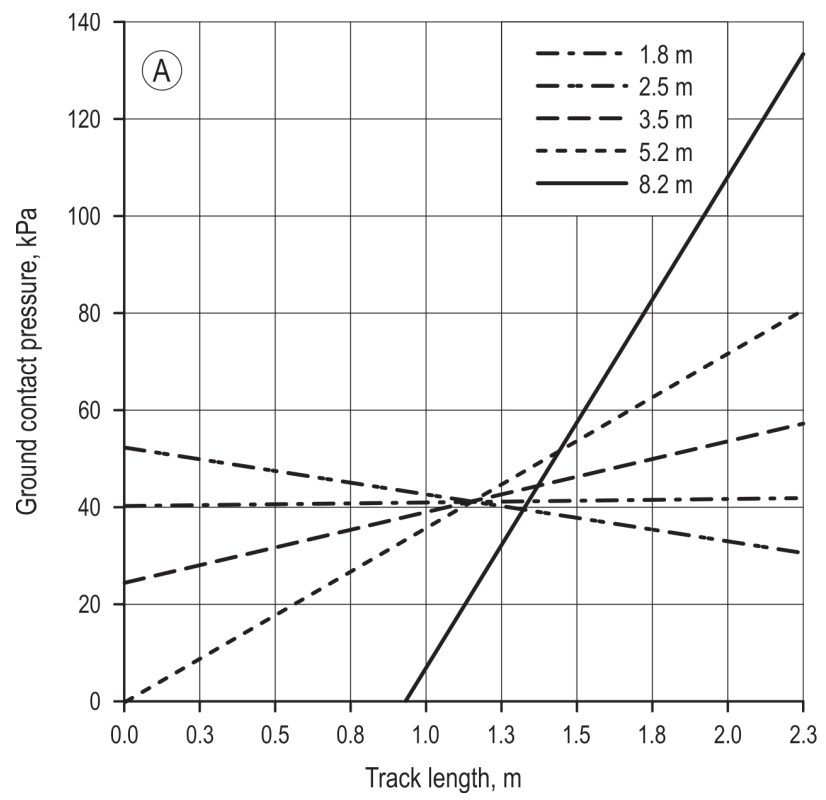

in the ground contact pressure value is variable over the length of the track (Table 3, Fig. 5B).

Such a situation is theoretical and would occur if there was no track on the chassis or if it was not tightened and the ground had low load capacity. In this case the ground contact pressures on the supporting wheels at the outer ends of the track would be high. With the crane maximum forward extension, the ground contact pressures on the front wheel of the track are up to $276.8 \mathrm{kPa}$.

In the theoretical variant, when it is assumed that the load is captured in the harvester head, the maximum range, at which the pressure is consistent with the shape of a triangle and exerted along the entire length of the track, occurs when the crane is extended

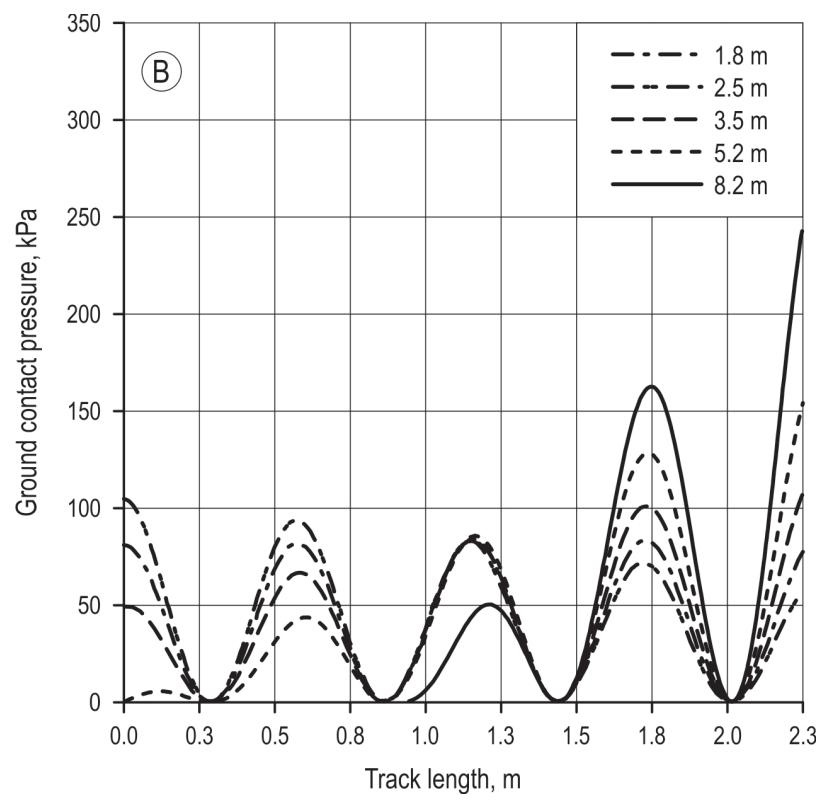

Fig. 5 Distribution of ground contact pressure under track with crane extended forward in homogeneous variant (A), and a point impact variant (B) 
Table 3 Weight indications and results of calculation of active track length and track-ground contact pressures with a simulated 2 kN load lift

\begin{tabular}{|c|c|c|c|c|c|c|c|}
\hline \multicolumn{2}{|c|}{ Crane extension } & \multirow{3}{*}{$\begin{array}{l}\text { Length of the } \\
\text { area of impact } \\
I_{\mathrm{t}}\left(V_{\mathrm{t}}{ }^{\prime}\right), \mathrm{m}\end{array}$} & \multicolumn{5}{|c|}{ Ground contact pressures, kPa } \\
\hline \multirow{2}{*}{ Determination } & \multirow{2}{*}{ Value, $\mathrm{m}$} & & \multicolumn{3}{|c|}{ Homogeneous impact, track extremes } & \multicolumn{2}{|c|}{ Point impact, track extremes } \\
\hline & & & $P_{\text {avg }}$ & $P_{\mathrm{ft}}$ & $P_{\mathrm{ff}}$ & $P_{\mathrm{fr}}$ & $P_{\mathrm{ff}}$ \\
\hline$L_{\mathrm{f1}}$ & 1.8 & 2.3 & 42.3 & 46,0 & 38,3 & 87.2 & 81.0 \\
\hline$L_{\mathrm{f} 2}$ & 2.5 & 2.3 & 42.3 & 32,3 & 52,3 & 59.8 & 108.5 \\
\hline$L_{f 3}$ & 3.5 & 1.3 & 42.3 & 13,8 & 70,7 & 22.9 & 145.6 \\
\hline$L_{f 4}$ & 5.2 & 1.82 & 53.3 & 0,0 & 102,9 & 0.0 & 205.9 \\
\hline$L_{\mathrm{f5}}$ & 8.2 & 0.72 & 136.0 & 0,0 & 249,3 & 0.0 & 498,5 \\
\hline
\end{tabular}
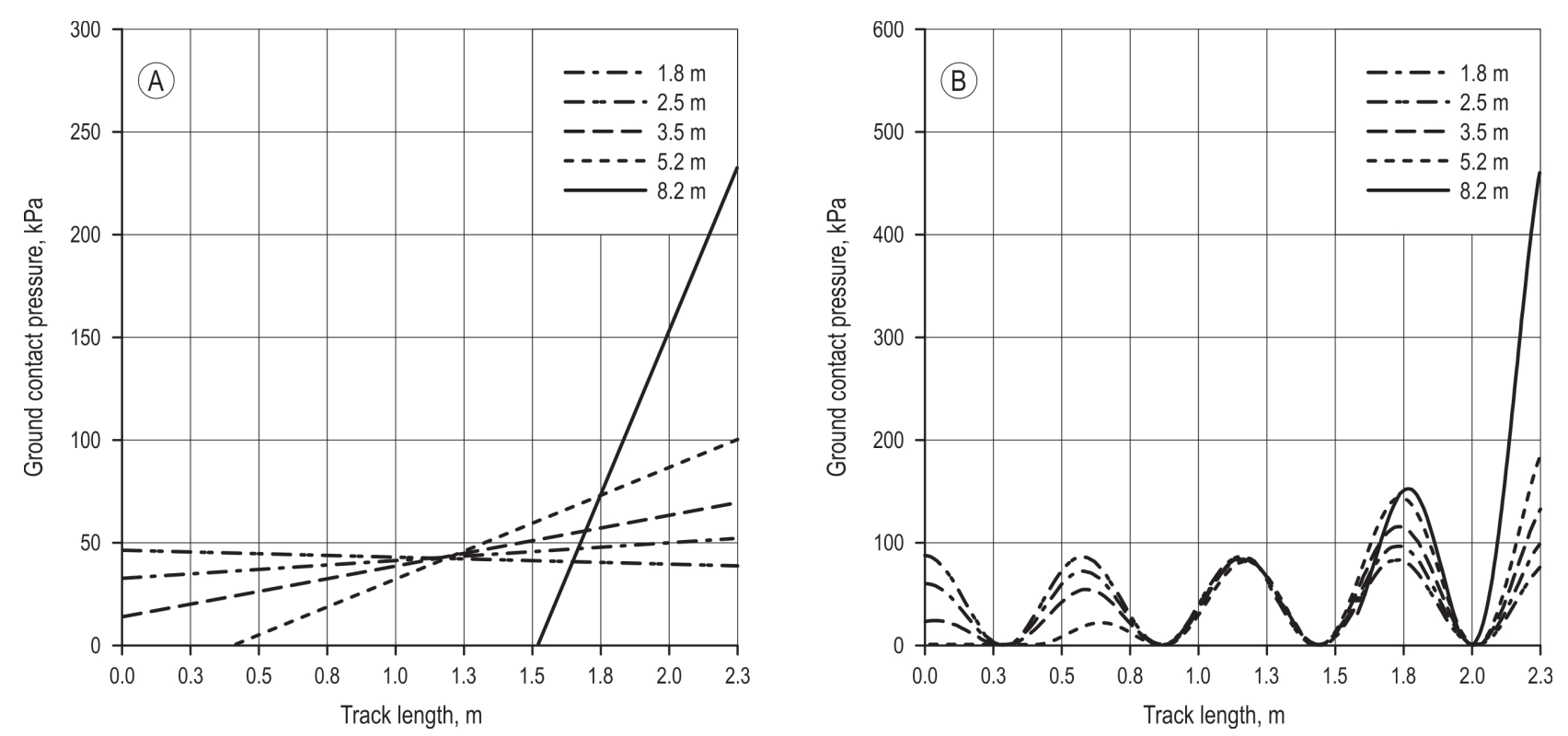

Fig. 6 Distribution of ground contact pressures under track with a simulated load lift of 2 kN, according to crane extension forward in homogeneous variant $(A)$, and a point impact variant $(B)$

forward to a distance of up to $3.5 \mathrm{~m}$. When the crane was extended over $8.2 \mathrm{~m}$, the active length of the track $l_{\mathrm{t}}^{\prime}$, which carried the load to the ground, was only $0.72 \mathrm{~m}$ $\left(l_{\mathrm{t}}=2.3 \mathrm{~m}\right)$, while the ground contact pressure of the front end of the track reached $249.3 \mathrm{kPa}$ (Table 4, Fig. $6 \mathrm{~A})$.

Table 4 Indication of hydraulic weight and results of calculation of track loads when the crane is extended to machine side in unloaded and loaded versions

\begin{tabular}{|c|c|c|c|c|c|c|}
\hline \multicolumn{2}{|c|}{ Crane extension } & \multirow{3}{*}{$\begin{array}{c}\text { Weight } \\
\text { indications } \\
\text { on scale } R_{\mathrm{us}}, \mathrm{kN}\end{array}$} & \multicolumn{4}{|c|}{ Ground contact pressures, $\mathrm{kPa}$} \\
\hline \multirow{2}{*}{ Determination } & \multirow{2}{*}{ Value, $m$} & & \multicolumn{2}{|c|}{ Without load } & \multicolumn{2}{|c|}{ With load } \\
\hline & & & Unloaded track $P_{u}$ & Loaded track $P_{1}$ & Unloaded track $P_{\mathrm{u}}$ & Loaded track $P_{\mathrm{I}}$ \\
\hline$L_{\text {s11 }}$ & 1.8 & 19.8 & 38.2 & 44.4 & 34.6 & 50.0 \\
\hline$L_{\mathrm{s} 12}$ & 3.0 & 17.0 & 32.8 & 49.9 & 26.8 & 57.8 \\
\hline$L_{\mathrm{s} 13}$ & 5.4 & 13.3 & 25.6 & 57.0 & 14.6 & 70.0 \\
\hline$L_{\mathrm{s} 14}$ & 7.9 & 9.2 & 17.8 & 64.9 & 1.9 & 82.7 \\
\hline$L_{\mathrm{s} 15}$ & 8.9 & 7.7 & 14.8 & 67.9 & -3.1 & 87.7 \\
\hline
\end{tabular}



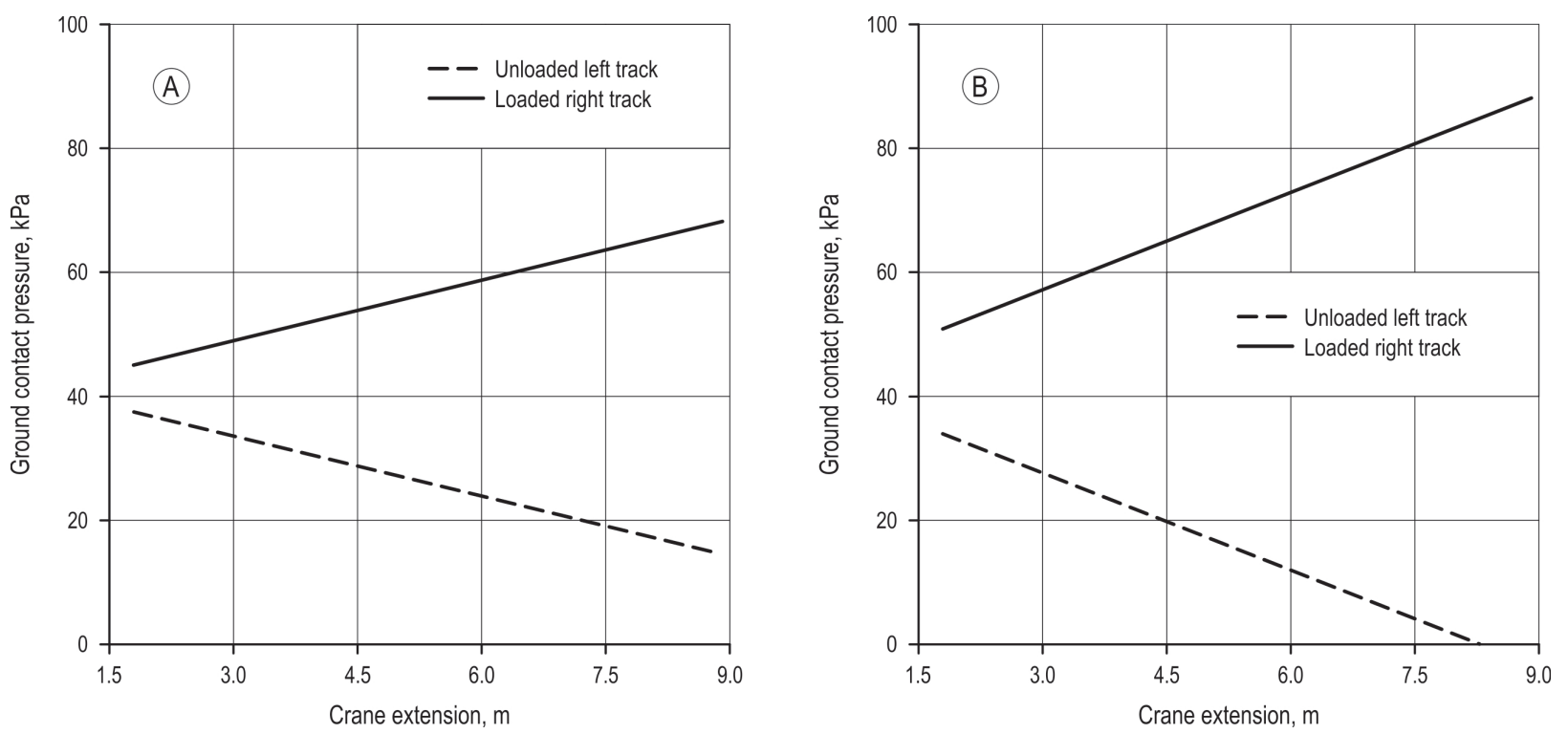

Fig. 7 Pressure distribution under crawler tracks according to crane sideways extension in unloaded variant (A), and variant with a simulated load of $2 \mathrm{kN}(\mathrm{B})$

In the theoretical calculation of the ground contact pressures, when the impact on the soil is a point from the track support wheels and the ground on which the machine moves has a low load capacity, the ground contact pressures reach very high values up to $498,5 \mathrm{kPa}$ for crane extension to $8.2 \mathrm{~m}$ (Table 4, Fig. 6B).

When analyzing the contact pressure exerted on the ground during the crane extension to the left of the machine (Table 5, Fig. 7A) by $8.9 \mathrm{~m}$, the pressure under the crawler track additionally loaded to $67.9 \mathrm{kPa}$ will increase. A load of $2 \mathrm{kN}$ captured in the harvester head without losing contact between the loaded track and the ground can be lifted during the extension by a maximum of $8.25 \mathrm{~m}$ (Table 5, Fig. 7B).

\section{Discussion}

From the measurements and calculations carried out, it can be concluded that the issue of changes in the values of contact pressures exerted on the ground of the crawler track system is complicated. The assumption that a track applies a uniform contact pressure on the ground with a constant value over its entire length is a great simplification. When the track is applied to the ground, the contact pressure varies depending on the weight of the tree that is currently being processed by the harvester head, but also on the distance and direction of the machine crane extension. The ground contact pressure can vary considerably under the track and reach high values when only the active part of the track affects the ground. In the analyzed case, the crane was extended forward along the longitudinal axis of the machine to a distance close to the maximum. With a simulated crane load of $2 \mathrm{kN}$, such a long extension of the crane to $8.2 \mathrm{~m}$ could cause the average ground contact pressure of up to $139 \mathrm{kPa}$. The average value determined for the variant with a long crane reach, with and without load, exceeds the value of $50 \mathrm{kPa}$ given by Matthies et al. (1995). The authors claim that below that value, for a single pass, there are no significant changes in soil structure and that soil quality does not deteriorate. According to Grećenko (1994), below $100 \mathrm{kPa}$, the changes that will occur in the soil can be expected to be reversible. However, the values at the ends of the track are unfavorable, as they approach $150 \mathrm{kPa}$, which may indicate that there will be larger and deeper changes in the soil structure (Grećenko 1994, Matthies et al. 1995, Malík and Dvořák 2007). When considering the extension of the crane, at an angle of $90^{\circ}$ to the longitudinal axis of the machine, at a distance close to the maximum $(8.9 \mathrm{~m})$, there was a significant increase in ground contact pressures, reaching $67.9 \mathrm{kPa}$ on the loaded track and $14.8 \mathrm{kPa}$ on the relieved track. In case of the variant with simulated load of $2 \mathrm{kN}$, extending the crane to a distance of more than $8.25 \mathrm{~m}$ could cause the machine to tip over to the side. To sum up, it can be stated that the average ground contact pressures under the track of the analyzed harvester met the assumed criterion of $70 \mathrm{kPa}$ (Więsik 1996, Neruda 2008) or slightly exceeded them. Therefore, the impact on the soil was not expected to 
be negative. When the extension of the crane was loaded, which would result in the impact of tracks on the ground with the average pressure exceeding the assumed criterion, the impact was limited by machine stability conditions. High ground contact pressures under the tracks can occur during operation, but only under a fragment of the more loaded active length of the track, and then local excessive soil loading may occur. It should also be noted that the determined ground contact pressures were static, yet as a rule the harvester chassis is affected by dynamic forces related to the operation of the machine, and in this case by varying speeds of movement in three directions of both the load and the machine components themselves (crane, head, slewing unit). The actual momentary dynamic ground contact pressures can therefore be much higher. Another aspect of the issue under consideration is how the actual crawler track, due to its design and operating conditions, affects the ground. In the case of simulation calculations, assuming that the interaction of the track system is heterogeneous, variable and related to the number of wheels in the track, its tension and load capacity of the ground indicate that the ground contact pressures exerted when the track is weakly tensioned can reach very high values, especially when combined with higher loads on the track fragments related to machine operation and low load capacity of the ground. The high ground contact pressures obtained in some cases may indicate the creation of a local variable, depending on the situation, impyling significant impact on the ground, which may result in the local significant soil depression, while in places of those cavities the soil may be subject to compaction with permanent negative effects (Murphy 2005, Haas 2015, Cambi et al. 2015, Solgi et al. 2019).

\section{Conclusions}

On the basis of the tests carried out, it can be concluded that during operation, the ground contact pressures exerted by the harvester tracks change significantly depending on the crane extension degree and direction, and the weight of trees being processed. When the crane extends over longer distances and when handling a heavy tree, the active length of the track may be shortened, resulting in a considerable increase in the ground contact pressure exerted on the soil and exceeding the average value of the recommended ground contact pressure of $70 \mathrm{kPa}$, over the entire active length of the track and, above all, on a section of the track. When the crane is pulled forward to the maximum distance, the ground contact pressure in the front of the track can increase by over $220 \%$, and when extended perpendicular to the machine, by over $52 \%$, compared to the pressure with the folded crane. Such high pressures may have a local impact on forest soil.

\section{Acknowledgments}

The conducted research is supported by the Polish National Agency for Academic Exchange from Poland and Ministries of Education Youth and Sports from Czech Republic under the projects PPN/BCZ/2019/ 1/00013 (Poland) and 8J20PL062 (Czech Republic) "Analysis of the Impact of Harvester Technology on Forest Ecosystem Depending on Work Performance«, run by University of Agriculture in Krakow and Czech University of Life Sciences Prague. Also thanks to Łukasz Duszyński PhD, who helped with data collection.

\section{References}

Adams, P.W., 1981: Compaction of forest soils. Oregon State University Extension Service. PNW, 217; 14 p.

Akay, A.E., Yuksel, A., Reis, M., Tutus, A., 2007: The Impacts of Ground-Based Logging Equipment on Forest Soil. Polish Journal of Environmental Studies 16(3): 371-376.

Allman, M., Jankovský, M., Messingerová, V., Allmanová, Z., Ferenčík, M., 2015: Soil compaction of various Central European forest soils caused by traffic of forestry machines with various chassis. Forest Systems 24(3): 1-10. https://doi. org/10.5424/fs/2015243-07541

Ampoorter, E., Goris, R., Cornelis, W.M., Verheyen, K., 2007: Impact of mechanized logging on compaction status of sandy forest soils. Forest Ecology and Management 241(1-3): 162-174. https://doi.org/10.1016/j.foreco.2007.01.019

Ampoorter, E., Van Nevel, L., De Vos, B., Hermy, M., Verheyen, K., 2010: Assessing the effects of initial soil characteristics, machine mass and traffic intensity on forest compaction. Forest Ecology and Management 260(10): 1664-1676. https://doi.org/10.1016/j.foreco.2010.08.002

Braunack, M.V., 1986: The residual effects of tracked vehicles on soil surface properties. Journal of Terramechanics 23(1): 37-50. https://doi.org/10.1016/0022-4898(86)90030-3

Cambi, M., Certini, G. Neri, F., Marchi, E., 2015: The impact of heavy traffic on forest soils: A review. Forest Ecology and Management 338: 124-138. https://doi.org/10.1016/j.foreco.2014.11.022

Dajniak, H., 1974: Ciągniki teoria ruchu i konstruowanie (Tractor theory of motion and construction). Wydawnictwo Komunikacji i Łączności, Warszawa, Poland, 720 p.

Dvořák, J., Bystrický, R., Hošková, P., Hrib, M., Jarkovská, M., Kováč , J., Krilek, J., Natov, P., Natovová, L., 2011: The 
use of harvester technology in production forests. Forestalia, Czech Republic, 156 p.

Grećenko, A., 1994: Vlastnosti ternnch vozidel. Praha VSZ v Praze. Czech Republic; 118 p.

Haas, J., Schack-Kirchner, H., Lang, F., 2015: Gleisbildung bei der Befahrung mit Forwardern. Forst \& Technik 2: 20-24.

Ismoilov, A.Q., 2016: Suspended forestry machines for sustainable forestry. Doctoral thesis in Machine Design Stockholm, Sweden, $38 \mathrm{p}$.

Kormanek, M., 2016: Przenośna terenowa waga hydrauliczna (Portable hydraulic scale for measurements in the field). Patent nr P. 407832.

Kormanek, M., Banach, J., Sowa, P., 2015a: Effect of soil bulk density on forest tree seedlings. International Agrophysics 29(1): 67-74. https://doi.org/10.1515/intag-2015-0003

Kormanek, M., Głąb, T., Banach, J., Szewczyk, G., 2015b: Effects of soil bulk density on sessile oak Quercus petraea Liebl. seedlings. European Journal of Forest Research 134: 969-979. https://doi.org/10.1007/s10342-015-0902-2

Kremer, J., Matthies, D., Borchert, H., 2007: The impact of different carriages on soil and roots - wheels and tracks in comparison. Proceedings of Austro 2007 - FORMEC'07 »Meeting the Needs of Tomorrows' Forests: New Developments in Forest Engineering «, October 7-11, Wien-Heiligenkreuzl, Austria, University of Natural Resources and Applied Life Sciences Viena, CD-ROM, 1-9.

Lukáč, M., 2005: Viacoperačné stroje v lesnom hospodástve. Technická univerzita vo Zvolene, Zvolen, 137 p.

Malík, V., Dvořák, J., 2007: Harvestorové technologie a vliv na lesní porosty. Folia forestalia Bohemica, Lesnická práce 5, $80 \mathrm{p}$.

Marusiak, M., Neruda, J., 2018: Dynamic Soil Pressures Caused by Travelling Forest Machines. Croatian Journal of Forest Engineering 39(2): 233-245.

Matthies, D., Weixler, H., Guglhör, W., Löffler, H., 1995: Bodenuntersuchungen zu befahrungsbedingten Strukturveränderungen auf Waldstandorten in Bayern. Abschlußbericht Kuratoriumsprojekt A30, Freising, 121 p.

MHT 8002HV 2005: Information material - Mechhydronic Ges.m.b.H., 6 p.

Murphy, M., Firth, J.G., Skinner, M.F., 2004: Long-term impacts of forest harvesting related soil disturbance on log product yields and economic potential in a New Zealand forest. Silva Fennica 38(2): 279-289. https://doi.org/10.14214/ sf.416

Naghdi, N., Solgi, A., 2014: Effects of Skidder Passes and Slope on Soil Disturbance in Two Soil Water Contents. Croatian Journal of Forest Engineering 35(1): 73-80.

Naghdi, R., Solgi, A., Labelle, E.R., Zenner, E.K., 2016: Responses of soil physical and chemical properties and maple (Acer velutinum Boiss) seedling growth to soil compaction following ground-based skidding. European Journal of Forest Research 135(5): 949-962.

Neruda, J., 2008: Determination of damage to soil and root system of forest trees by the operation of logging machines. Monograph. Mendel University of Agriculture and Silviculture, Brno, Czech Republic, 140 p.

Poršinsky, T., Pentek, T., Bosner, A., Stankić, I., 2012: Ecoefficient Timber Forwarding on Lowland Soft Soils. In: Global Perspectives on Sustainable Forest Management (ed: C. A. Okia), In Tech, 275-288.

Saarilahti, M., 2002: Modelling of the wheel and tyre, 1. Tyre and soil contact - Survey on tyre contact area and ground pressure models for studying the mobility of forest tractors. Soil interaction model, Appendix Report No 5, 1-43.

Sakai, H., Nordfjell, T., Suadicani, K., Talbot, B., Bollehuus, E., 2008: Soil Compaction on Forest Soils from Different Kinds of Tires and tracks and Possibility of Accurate Estimate. Croatian Journal of Forest Engineering 29(7): 15-27.

Solgi, A., Naghdi, R., Labelle, E.R., Behjou, F.K., Hemmat, V., 2019: Evaluation of Different Best Management Practices for Erosion Control on Machine Operating Trails. Croatian Journal of Forest Engineering 40(2): 341-350. https://doi. org/10.5552/crojfe.2019.532

Solgi, A., Naghdi, R., Marchi, E., Behjou, F.K., Hemmati, V., 2019: Assessment of ground-based skidding impacts on physical and chemical properties of forest soils and their effects on maple seedling growth along the margin of the skid trail. Forests 10(2): 134-150. https://doi.org/10.3390/f10020134

Tan, X., Kabzem, R., Chang, S.X., 2006: Response of forest vegetation and foliar $\delta 13 \mathrm{C}$ and $\delta 15 \mathrm{~N}$ to soil compaction and forest floor removal in a boreal aspen forest. Forest Ecology and Management 222(1-3): 450-458. https://doi.org/10.1016/j. foreco.2005.10.051

Ulrich, R., Neruda, J., Valenta, J., 2003: Wpływ układów jezdnych wybranych maszyn na glebę (Impact of chassis systems of selected machines on soil). Inżynieria Rolnicza 11(53): 229-235.

Visser, R., Stampfer, K., 2015: Expanding Ground-based Harvesting onto Steep Terrain: A Review. Croatian Journal of Forest Engineering 36(2): 321-331.

Wang, J.I., 2009: Terramechanics and Off-Road Vehicle Engineering: Terrain Behaviour, Off-Road Vehicle Performance and Design, Butterworth-Heinemann, 397 p.

Więsik, J., 1996: Możliwości doboru maszyn przyjaznych dla środowiska leśnego. (The possibilities of choosing forestfriendly machines). Przegląd Techniki Rolniczej i Leśnej 1: 13-15.

Wijekoon, M., Sellgren, U., Prnazarov, A,. Löfgren, B., 2012: Forest machine tire-soil interaction. Proceedings of the $45^{\text {th }}$ International Symposium on Forestry Mechanisation (FORMEC) »Forest Engineering - Concern, Knowledge and Accountability in Today's Environment«, October 8-12, Cavtat/ Dubrovnik, Croatia, 1-14. 
(C) 2021 by the authors. Submitted for possible open access publication under the terms and conditions of the Creative Commons Attribution (CC BY) license (http://creativecommons.org/licenses/by/4.0/).

Authors' addresses:

Assist. prof. Mariusz Kormanek, $\mathrm{PhD}$ * e-mail: rlkorma@cyf-kr.edu.pl University of Agriculture in Krakow Faculty of Forestry Department of Forest Utilization Engineering and Forest Technology Al. 29 Listopada 46, Krakow 31-423

POLAND

Assist. prof. Jiří Dvořák, PhD e-mail: dvorakj@fld.czu.cz Czech University of Life Sciences Prague Faculty of Forestry and Wood Sciences Institute of Forest Use of Forest Engineering and Technology Kamycka 1176 16521 Prague 6 - Suchdol CZECH REPUBLIC

* Corresponding author 
